\title{
The Effects of Exposure to Ozone on Collagen in Lungs and Skin
}

\author{
Osamu Fukase and Kiyosumi Hashimoto
}

Public Health Institute of Hyogo Prefecture

\section{INTRODUCTION}

Studies of the toxicity of inhaled ozone, a major constituent of photochemical smog, have shown that long-term exposure to ozone at near-ambient concentrations results in morphologic changes in the pulmonary tract characterized by increased accumulation of connective tissue components in bronchioles and alveolar ducts ${ }^{1 \sim 4)}$. Biochemical studies have also shown the ozone-induced synthesis increased and that it is collagen which accumulates most in connective tissues ${ }^{4,5}$. Such findings indicate that increases in the amount of collagen in the lungs may relate to pulmonary fibrosis and may indicate a chronic condition caused by ozone. Collagen isolated from various human and animal tissues has properties which depend on the age of the subject. For example, the solubility of dermal collagen varies with age, that is, the soluble collagen extractable from the skin decreases with age $e^{6 \sim 8)}$. This indicates that the collagen has become more rigid and stable with the passage of time. Therefore, it can be expected that the collagen which has accumulated in the lungs due to exposure to ozone may affect collagen's overall solubility here.

The present study was undertaken to evaluate the effects of ozone exposure on lung collagen. Experiments were designed to investigate collagen level and its solubility in the lungs of mice and rats exposed to ozone. The collagen level was compared with that of reduced glutathione (GSH) which has been shown to be both a sensitive and quantitative indicator to monitor the effects of ozone ${ }^{9}$. Since collagen in the lungs of adult animals is almost insoluble either in a neutral salt or an acetic acid solution, both of which can extract collagen without denaturation ${ }^{10,11)}$, solubility was measured following the procedure described by Nimni et al. ${ }^{8)}$ in which cysteamine solubilized significant amounts of insoluble collagen.

Solubility was also examined in rat dermal collagen to clarify the effects of ozone on skin as longterm exposure to nitrogen dioxide has previously been shown to induce increases in total and soluble collagen levels in the skin of guinea pigs $^{12}$.

\section{MATERIALS AND METHODS}

Two hundreds and twenty male 4-week-old ICR-Jcl mice and eighty SD-Jcl rats obtained from a breeding laboratory (CLEA Japan, Inc., Tokyo) were used. The animals were maintained on commercial chow and water ad lib. except during exposure periods. The experimental environment was controlled to a temperature of $22 \pm 2^{\circ} \mathrm{C}$.

Groups of 120 mice each of 5-week-old were exposed to $0.2,0.5,1.0$, and $1.7 \mathrm{ppm}$ ozone 4 hours a day for 5 days or to $1.0 \mathrm{ppm}$ ozone 4 hours a day for $10,20,30$, or 40 days. Four-fifth animals subjected to the 40 days exposure were returned to pre-experimental conditions for $4,10,18$, or 28 days. Groups of 40 rats were exposed to $1.0 \mathrm{ppm}$ ozone 4 hours a day, 5 days a week, for $1,3,6$, or 10 weeks. An equivalent chronological series of 10 each of control animals was kept under ambient conditions. A detailed description of the exposure procedure is given elsewhere ${ }^{9)}$.

All mice were sacrificed by cervical dislocation and the lungs were removed, blotted, weighed, and homogenized in $8 \mathrm{~m} l$ of an ice-cold $0.02 \mathrm{M}$ disodium ethylenediaminetetraacetate solution. For the GSH assay, $5 \mathrm{~m} l$ of homogenate was used with the remainder kept for the collagen assay. GSH was determined in the form of non-protein sulfhydryls following the method of Sedlak and Lindsay ${ }^{13)}$. Independent determinations of GSH gave values which account for $95 \%$ of the non-protein sulfhydryls in 
the homogenates ${ }^{14)}$. Collagen was determined from the hydroxyproline content of acid hydrolyzates in the homogenates following Woessner ${ }^{15}$. In the presence of $6 \mathrm{~N}$ hydrochloric acid, $3 \mathrm{~m} l$ of homogenate was hydrolyzed for 3 hours at $130^{\circ} \mathrm{C}$ and dried in a vacuum at $70^{\circ} \mathrm{C}$. The dried hydrolyzate was resuspended in $8 \mathrm{~m} l$ of water and filtered through filter paper. Aliquots of the filtrates were used to measure hydroxyproline which converts to its collagen equivalent multiplied by a factor of $7.46^{16)}$. In this procedure, the elastin which inevitably coexists and contains about $2 \%$ hydroxyproline was not removed from the sample to be assayed. In the lungs, however, the amount of hydroxyproline derived from elastin is only about $6 \%$ of that derived from collagen ${ }^{17}$, and thus is not significant.

Rats were killed by cerebral concussion. The lungs and approximately $0.5 \mathrm{~g}$ of dorsal skin were removed, blotted, weighed, and lyophylized. The dried samples were used to estimate collagen solubility according to a slightly modified form of the method of Nimni et al. ${ }^{8}$ described below. Each sample was homogenized in $30 \mathrm{~m} l$ of ice water with a Polytron homogenizer until the sample was disintegrated. The homogenate was centrifuged at a temperature of $4^{\circ} \mathrm{C}$ at $40,000 \mathrm{~g}$ for 1 hour. The precipitate was homogenized in water and centrifuged again and finally homogenized in $30 \mathrm{~m} l$ of ice-cold $0.5 \mathrm{M}$ sodium chloride solution. The resulting suspension was shaken overnight at $4^{\circ} \mathrm{C}$ and centrifuged a third time. The final supernatant solution was considered to represent the salt-soluble collagen fraction and the resulting precipitate was extracted overnight at $4^{\circ} \mathrm{C}$ with $30 \mathrm{ml}$ of $0.5 \mathrm{M}$ acetic acid solution in the case of the lung sample or $30 \mathrm{~m} l$ of $0.5 \mathrm{M}$ citrate buffer solution ( $\mathrm{pH} \mathrm{3.6)}$ in the case of skin. The acid-soluble collagen fraction was obtained after the centrifugation and the resulting precipitate was further extracted for 3 days at $4^{\circ} \mathrm{C}$ with $30 \mathrm{~m} l$ of $0.2 \mathrm{M}$ cysteamine solution in $0.6 \mathrm{M}$ sodium chloride $(\mathrm{pH} 7.0)$. The cysteamine-soluble and insoluble fractions were separated by centrifugation. Each supernatant fraction was concentrated in a collodion bag (Sartorius Membranfilter $\mathrm{GmbH}$, Göttingen) and constituted the insoluble residue. The residues were washed with water several times and finally suspended in a small amount of water. The insoluble collagen fraction was washed with water once and was also suspended in $3 \mathrm{~m} l$ of water. The above suspensions were used to determine collagen as described above. About $90 \%$ of the total collagen was thus recovered.

\section{RESULTS}

Table 1 shows the effects of exposure to ozone for 5 days on GSH and collagen levels in mouse lungs. GSH levels increased linearly as a function of ozone concentration. GSH increased by 4.8 to $25.0 \%$ ( $p<$ 0.05 level of significance) following exposure to from 0.2 to $1.7 \mathrm{ppm}$ ozone. The linear regression coefficient between ozone concentration and GSH was $0.997(\mathrm{p}<0.01)$. On the other hand, there was no change in collagen following ozone exposure, although lung wet weights increased significantly at $1.0 \mathrm{ppm}$ or more.

The effects of exposure to $1.0 \mathrm{ppm}$ ozone for 0 to 40 days on the GSH and collagen levels in mouse lungs are shown in Figure 1. GSH levels increased significantly as a function of exposure duration up to 30 days and then decreased at 40 days although the levels remained significantly higher than those of

Table 1 Effects of Five Days Exposure to Ozone on GSH and Collagen Levels in Mouse Lungs*

\begin{tabular}{lccc}
\hline Ozone & $\mathrm{n}$ & $\mathrm{GSH}$ & Collagen \\
\hline ppm & & nmole/lung & $\mathrm{mg} /$ lung \\
0.0 (Controls) & 20 & $421 \pm 6$ & $1.68 \pm 0.04$ \\
0.2 & 10 & $441 \pm 6$ & $1.74 \pm 0.06$ \\
0.5 & 10 & $452 \pm 10$ & $1.72 \pm 0.06$ \\
1.0 & 10 & $484 \pm 6$ & $1.68 \pm 0.06$ \\
1.7 & 10 & $526 \pm 10$ & $1.76 \pm 0.06$ \\
\hline
\end{tabular}

* Data are expressed as the mean $\pm \mathrm{SE}$. the controls $(\mathrm{p}<0.01)$. Collagen levels were steady at the tenth day but then increased linearly as a function of exposure duration. At the fortieth day, the level was $26.0 \%$ higher than the control level $(p<0.05)$. Figure 2 shows GSH and collagen levels in the lungs of mice exposed to $1.0 \mathrm{ppm}$ ozone for 40 days, which were then returned to pre-experimental conditions. The GSH had decreased sharply and was at the control level by the tenth day, whereas although the collagen level had also decreased, it was at a much slower rate. In fact, collagen levels remained elevated even 28 days after ozone had been discontinued $(9.2 \%$ higher than controls, but not significant). 


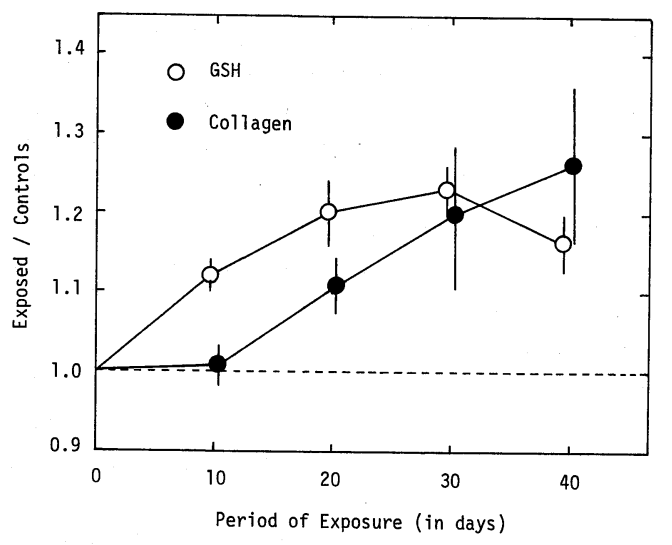

Fig. 1. Effects of repeated exposure to $\mathbf{1 . 0} \mathbf{~ p p m}$ ozone on GSH and collagen levels in mouse lungs. Circles represent means and extended lines, SE's $(n=10)$.

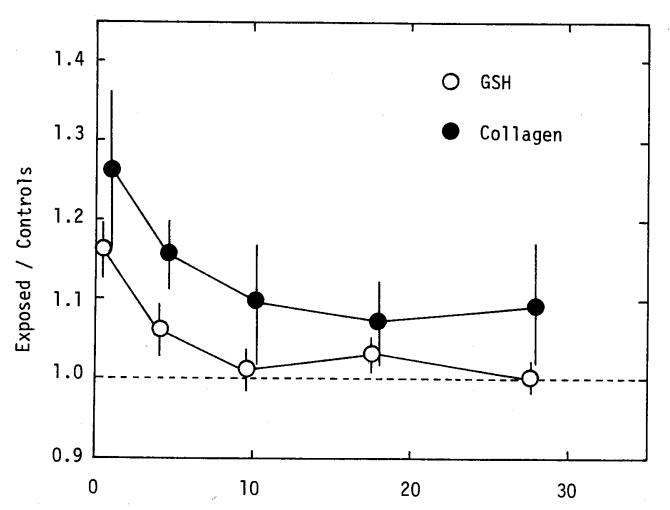

Period after 0zone Exposure had been Discontinued (in days)

Fig. 2. GSH and collagen levels. in mouse lungs following the end of the 40-day exposure to $1.0 \mathrm{ppm}$ ozone. Circles represent means and extended lines, SE's $(n=10)$.

Table 2 Collagen Levels and Percentage Distributions of the Different Fractions Extracted from the Lungs of Ozone-exposed and Control Rats*

\begin{tabular}{|c|c|c|c|c|c|}
\hline \multirow{2}{*}{$\begin{array}{l}\text { Period of } \\
\text { Exposure }\end{array}$} & \multicolumn{4}{|c|}{ Collagen Fractions } & \multirow{2}{*}{$\begin{array}{c}\text { Total } \\
\text { Collagen }\end{array}$} \\
\hline & $\begin{array}{c}\text { Salt } \\
\text { Soluble } \\
\end{array}$ & $\begin{array}{c}\text { Acid } \\
\text { Soluble } \\
\end{array}$ & $\begin{array}{c}\text { Cysteamine } \\
\text { Soluble }\end{array}$ & Insoluble & \\
\hline & $\mathrm{mg} /$ lung & $\mathrm{mg} /$ lung & $\mathrm{mg} /$ lung & mg/lung & $\mathrm{mg} /$ lung \\
\hline 1 week & $\begin{array}{c}0.05 \pm 0.01 \\
\quad(0.5)\end{array}$ & $\begin{array}{c}0.06 \pm 0.00 \\
\quad(0.5)\end{array}$ & $\begin{array}{c}0.03 \pm 0.01 \\
\quad(0.3)\end{array}$ & $\begin{array}{c}10.2 \pm 0.5 \\
\quad(98.6)\end{array}$ & $\begin{array}{c}10.3 \pm 0.5 \\
\quad(100)\end{array}$ \\
\hline Controls & $\begin{array}{c}0.05 \pm 0.00 \\
(0.6)\end{array}$ & $\begin{array}{c}0.05 \pm 0.01 \\
\quad(0.6)\end{array}$ & $\begin{array}{c}0.02 \pm 0.01 \\
(0.2)\end{array}$ & $\begin{array}{c}9.0 \pm 0.7 \\
(98.6)\end{array}$ & $\begin{array}{c}9.2 \pm 0.7 \\
(100)\end{array}$ \\
\hline 3 weeks & $\begin{array}{l}0.04 \pm 0.01 \\
(0.2)\end{array}$ & $\begin{array}{l}0.07 \pm 0.01 \\
(0.4)\end{array}$ & $\begin{array}{c}0.05 \pm 0.01 \\
(0.3)\end{array}$ & $\begin{array}{c}16.3 \pm 0.8 \\
(99.0)\end{array}$ & $\underset{(100)}{16.5 \pm 0.8}$ \\
\hline Controls & $\begin{array}{l}0.03 \pm 0.01 \\
\quad(0.2)\end{array}$ & $\begin{array}{l}0.06 \pm 0.01 \\
\quad(0.4)\end{array}$ & $\begin{array}{l}0.03 \pm 0.01 \\
\quad(0.2)\end{array}$ & $\begin{array}{c}14.6 \pm 0.9 \\
(99.2)\end{array}$ & $\begin{array}{c}14.7 \pm 0.9 \\
(100)\end{array}$ \\
\hline 6 weeks & $\begin{array}{l}0.03 \pm 0.00 \\
\quad(0.1)\end{array}$ & $\begin{array}{l}0.08 \pm 0.01 \\
\quad(0.4)\end{array}$ & $\begin{array}{c}0.07 \pm 0.01 \\
\quad(0.3)\end{array}$ & $\begin{array}{c}19.1 \pm 0.9 \\
(99.1)\end{array}$ & $\underset{(100)}{19.2 \pm 0.9}$ \\
\hline Controls & $\begin{array}{l}0.02 \pm 0.00 \\
\quad(0.1)\end{array}$ & $\begin{array}{c}0.06 \pm 0.01 \\
\quad(0.3)\end{array}$ & $\begin{array}{c}0.07 \pm 0.01 \\
\quad(0.4)\end{array}$ & $\begin{array}{c}17.3 \pm 1.3 \\
(99.1)\end{array}$ & $17 \underset{(100)}{4}$ \\
\hline 10 weeks & $\begin{array}{l}0.02 \pm 0.01 \\
(0.1)\end{array}$ & $\begin{array}{c}0.10 \pm 0.01 \\
(0.3)\end{array}$ & $\begin{array}{c}0.02 \pm 0.00 \\
(0.1)\end{array}$ & $\begin{array}{c}29.4 \pm 1.9 \\
(99.5)\end{array}$ & $\begin{array}{c}29.6 \pm 1.9 \\
(100)\end{array}$ \\
\hline Controls & $\begin{array}{c}0.02 \pm 0.01 \\
(0.1)\end{array}$ & $\begin{array}{c}0.07 \pm 0.02 \\
(0.3)\end{array}$ & $\begin{array}{c}0.02 \pm 0.00 \\
(0.1)\end{array}$ & $\begin{array}{c}21.3 \pm 1.4 \\
(99.5)\end{array}$ & $\underset{(100)}{21.4 \pm 1.4}$ \\
\hline
\end{tabular}

* Data are expressed as the mean $\pm \mathrm{SE}(n=8-10)$. The parentheses show the percentage distributions.

Table 2 shows the effects of the levels and solubility of collagen from the lungs of rats exposed to $1.0 \mathrm{ppm}$ ozone $1,3,6$, and 10 weeks. Total collagen increased with age. About $99 \%$ of the collagen was insoluble in salt, acid, or cysteamine solutions, although the insoluble fraction tended to increase with as the age of the animal increased. Both acid-soluble and insoluble collagen increased with increasing exposure. In the lungs of rats exposed for 10 weeks, the acid-soluble fraction increased $46 \%(p<0.1)$ and the insoluble fraction $38 \%(\mathrm{p}<0.01)$. However, the distribution between the fractions remained the same. Most of the lung collagen in 5-week-old mice was insoluble in salt, acid, or cysteamine solutions and the total soluble collagen was only $4 \%$. 
Table 3 Fractions of Collagen Extracted from the Skin of Rats Exposed to Ozone for 10 Weeks*

\begin{tabular}{lcc}
\hline & Exposed & Control \\
\hline & \% of wet weight & \% of wet weight \\
Salt Soluble & $1.1 \pm 0.1$ & $1.1 \pm 0.1$ \\
Acid Soluble & $0.9 \pm 0.1$ & $0.9 \pm 0.1$ \\
Cysteamine Soluble & $5.3 \pm 0.2$ & $5.3 \pm 0.2$ \\
Insoluble & $13.2 \pm 0.8$ & $12.5 \pm 0.7$ \\
Total & $20.5 \pm 1.0$ & $19.7 \pm 0.9$ \\
\hline
\end{tabular}

* Data are expressed as the mean $\pm \mathrm{SE}(\mathrm{n}=10)$.
The levels and solubility of collagen from rat skin did not change even after 10 weeks exposure to $1.0 \mathrm{ppm}$ ozone (Table 3 ). However, the moisture content of the skin decreased significantly, i. e. to $60.8 \pm$ $0.4 \%$ of wet weight in ozone-expo sed rats as opposed to $62.2 \pm 0.2 \%$ in controls $(\mathrm{p}<0.05)$.

\section{DISCUSSION}

The results indicate that collagen levels in lungs increase following relatively long-term exposure to ozone. Short-term exposure increases GSH and presumably also the rate of collagen synthesis ${ }^{4,5}$, but not the collagen levels themselves. Changes in lung collagen does not indicate the effects of ozone at early stages of exposure. In the long-term case, elevated collagen levels decrease more slowly than GSH after exposure is discontinued. Similar results have been demonstrated by Hussain et al. ${ }^{5}$ who found that an increase in the amount of collagen in the lungs of rats exposed continuously to $0.8 \mathrm{ppm}$ ozone occurred later than an increase in its synthesis rate and that collagen level remained elevated for up to 28 days after the animals were returned to ambient filtered air. It has been suggested that because both the synthesis and degradation of collagen in lungs may occur at the early stages of exposure, collagen levels appear unchanged. During the next stage when metabolic activity increases to protect the organism against ozone's oxidative toxicity, GSH increases, ${ }^{9)}$ the rate of collagen degradation decreases and thus the accumulation of collagen occurs. A possible structural change in lung collagen caused by ozone has been described by Buell et al. ${ }^{18)}$.

Accumulated collagen remaining in the lungs for a long period may reflect irreversible pulmonary changes such as pulmonary fibrosis ${ }^{1,2)}$, and increased collagen may be a quantitative monitor of the chronic effects of ozone. Collagen, however, is not specific for ozone toxicity and has been reported in animals exposed to high as well as low concentrations of oxygen ${ }^{19)}$, silica ${ }^{20,21)}$, and asbestos ${ }^{22)}$. On the other hand, when animals are exposed to nitrogen dioxide, there is a decrease in collagen levels in the lungs ${ }^{12,17)}$. Such differences between the actions of ozone and nitrogen dioxide are important when considering their individual biological effects.

An attempt to solubilize the collagen in mouse and rat lungs by treatment with cysteamine which can solubilize significant amounts of insoluble dermal collagen was unsuccessful here. It has been reported that salt-soluble collagen is newly synthesized and becomes acid-soluble and cysteamine-soluble with the passage of time ${ }^{8}$. Bradley et al. ${ }^{10)}$ have observed that less than $1-2 \%$ of the total collagen in adult rabbit lungs can be extracted with acetic acid and that even with the use of an inhibitor of the cross-linking of collagen molecules which increases the organic yield of soluble collagen, only $5 \%$ can be extracted from the lungs. This insolubility is believed to be due to covalent cross-links of tropocollagen and the association of collagen with proteoglycans and possibly with other proteins ${ }^{23,24}$. The exposure to ozone made no difference on the solubility of collagen in the lungs, indicating the ozone-induced collagen and the original form are identical in this respect.

Collagen fibers are found in the tracheobronchial tree, pulmonary blood vessels, and alveolar interstitium $\left.^{25} 27\right)$ and may play an important role in the lung's mechanical properties, however, it is still unclear to what extent accumulated collagen affects them. Bartlett et al. ${ }^{28)}$ have shown a decrease in lung tissue elasticity in rats exposed to $0.2 \mathrm{ppm}$ ozone for 30 days and suggested that this may caused by its effect on collagen. The study of elastin, another important component in pulmonary connective tissue and possibly a factor in lung mechanics ${ }^{2426,29)}$ is also necessary to further understand the effects of ozone. 
Kleinerman $^{17)}$ has demonstrated elastin and collagen degradation in hamsters exposed to nitrogen dioxide.

Skin which comes into direct contact with the ozone in air may be affected by its action. There is a loss of solubility when the soluble dermal collagen is exposed in vitro to the gaseous phase of tobacco smoke ${ }^{30}$. Soluble dermal collagen in guinea pigs exposed to nitrogen dioxide for 180 days has increased while insoluble collagen has decreased ${ }^{12}$. In the present study, the amounts and solubility of dermal collagen in rats were unchanged even after the 10 weeks' exposure to $1.0 \mathrm{ppm}$ ozone, although moisture content decreased. The period of exposure to ozone in this experiment may be insufficient to induce changes in the nature of dermal collagen. This loss of water from skin may be associated with the unthrifty appearance and coarseness of pelage observed in rabbits exposed to ozone for one year ${ }^{311}$.

Despite suggestive evidence that ozone may accelerate the aging process ${ }^{31)}$, there is little information concerning ozone-induced biochemical changes related to aging. Solubility is perhaps the simplest measure of the age-related properties of collagen. The present experiments, however, were ineffective in assessing the effects of ozone. More research is needed to study the effects on collagen of prolonged ozone exposure.

\section{SUMMARY}

The effects of repeated exposure to ozone on the levels and solubility of collagen in mouse and rat lungs and in rat skin were studied. The lung collagen levels of mice exposed to 0.2 to $1.7 \mathrm{ppm}$ ozone for 5 days remained unchanged, although GSH levels indicate the effects of ozone increased as a function of ozone concentration. A significant increase in lung collagen occurred in mice exposed to $1.0 \mathrm{ppm}$ ozone for 40 days. Raised collagen levels decreased more slowly than GSH levels after animals were returned to the original pre-experimental conditions. Collagen in mouse and rat lungs was almost completely insoluble in $0.5 \mathrm{M}$ sodium chloride, $0.5 \mathrm{M}$ acetic acid, or $0.2 \mathrm{M}$ cysteamine solutions. This insolubility continued when rats were exposed to $1.0 \mathrm{ppm}$ ozone for up to 10 weeks. Amounts and solubility of collagen in rat skin were also unchanged following exposure to $1.0 \mathrm{ppm}$ ozone for 10 weeks.

Acknowledgements: This work was supported in part by a grant from the Environmental Agency entitled "Studies of Biological Effects of Air Pollution" (1979-1980). Portions this paper were presented at the Fifty-first Annual Meeting of the Japanese Society for Hygiene (Sapporo, 1981) and the Twenty-second Annual Meeting of the Japan Society of Air Pollution (Akita, 1981).

\section{REFERENCES}

1) Scheel, L. D., Dobrogorski, O. J., Mountain, J. T., Svirbely, J. L., and Stokinger, H. E. : Physiologic, biochemical, immunologic and pathologic changes following ozone exposure, J. Appl. Physiol., 14, 67-80 (1959).

2) Freeman, G., Stephens, R. J., Coffin, D. L., and Stara, J. F. : Changes in dogs' lungs after long-term exposure to ozone. Light and electron microscopy, Arch. Environ. Health, 26, 209-216 (1973).

3) Freeman, G., Juhos, L. T., Furiosi, N. J., Mussenden, R., Stephens, R. J., and Evans, M. J.: Pathology of pulmonary disease from exposure to interdependent ambient gases (nitrogen dioxide and ozone), Arch. Environ. Health, 29, 203-210 (1974).

4) Last, J. A., Greenberg, D. B., and Castleman, W. L.: Ozone-induced alterations in collagen metabolism of rat lungs, Toxicol. Appl. Pharmacol., 51, 247-258 (1979).

5) Hussain, M. Z., Cross, C. E., Mustafa, M. G., and Bhatnagar, R. S.: Hydroxyproline contents and prolyl hydroxylase activities in lungs of rats exposed to low levels of ozone, Life Sci., 18, 897-904 (1976).

6) Bakerman, S. : Quantitative extraction of acid-soluble human skin collagen with age, Nature, 196, 375-376 (1962).

7) Nimni, M. E., de Guia, E., and Bavetta, L. A. : Changes in the quantity and nature of collagen in rabbit skin as a function of age, Nature, 207, 865-866 (1965).

8) Nimni, M. E., Deshmukh, K., and Bavetta, L. A.: Turnover and age distribution of a collagen fraction extractable from rat skin by mercaptoethylamine, Arch. Biochem. Biophys., 122, 292-298 (1967).

9) Fukase, O.: The effects of gaseous air pollutants on peroxidative metabolism in mouse lungs, Jpn. J. Hyg., 34, 777-792 (1980). 
10) Bradley, K. H., McConnell, S. D., and Crystal, R. G. : Lung collagen composition and synthesis. Characterization and changes with age, J. Biol. Chem., 249, 2674-2683 (1974).

11) Bradley, K., McConnell-Bruel, S., and Crystal, R. G. : Lung collagen heterogeneity (protein synthesis), Proc. Nat. Acad. Sci. USA, 71, 2828-2832 (1974).

12) Drózdz, M., Kucharz, E., and Szyja, J. : Effect of chronic exposure to nitrogen dioxide on collagen content in lung and skin of guinea pigs, Environ. Res., 13, 369-377 (1977).

13) Sedlak, J. and Lindsay, R. H. : Estimation of total, protein-bound, and nonprotein sulfhydryl groups in tissue with Ellman's reagent, Anal. Biochem., 25, 192-205 (1968).

14) Fukase, O. and Isomura, K. : Effects of metallic cadmium fumes on the peroxidative metabolism of mouse lungs, Hyogo-ken Eisei Kenkyusho Kenkyu Hokoku (Bull. Pub. Health Inst. Hyogo Prefecture), 11, 1-3 (1976).

15) Woessner, J. F. Jr.: The determination of hydroxyproline in tissue and protein samples containing small proportions of this imino acid, Arch. Biochem. Biophys., 93, 440-447 (1961).

16) Neuman, R. E. and Logan, M. A. : The determination of collagen and elastin in tissues, J. Biol. Chem., 186, 549-556 (1950).

17) Kleinerman, J. : Effects of nitrogen dioxide on elastin and collagen contents of lung, Arch. Environ. Health, 34, 228-232 (1979).

18) Buell, G. C., Tokiwa, Y., and Mueller, P. K. : Potential crosslinking agents in lung tissue. Formation and isolation after in vivo exposure to ozone, Arch. Environ. Health, 10, 213-219 (1965).

19) Chvapil, M. and Peng, Y. M. : Oxygen and lung fibrosis, Arch. Environ. Health, 30, 528-532 (1975).

20) Halme, J., Uitto, J., Kahanpää, K., Karhunen, P., and Lindy, S. : Protocollagen proline hydroxylase activity in experimental pulmonary fibrosis of rats, J. Lab. Clin. Med., 75, 535-541 (1970).

21) Chvapil, M., Eskelson, C. D., Stiffel, V., and Owen, J. A. : Early changes in the chemical composition of the rat lung after silica administration, Arch. Environ. Health, 34, 402-406 (1979).

22) Misra, V., Rahman, Q., and Viswanathan, P. N. : Biochemical changes in guinea pig lungs due to amosite asbestos, Environ. Res., 16, 55-61 (1978).

23) Bornstein, P.: The cross-linking of collagen and elastin and its inhibition in osteolathyrism, Am. J. Med., 49, 429-435 (1970).

24) Crystal, R. G. : Lung collagen : deffinition, diversity and development, Fed. Proc., 33, 2248-2255 (1974).

25) Pierce, J. A. and Ebert, R. V. : Fibrous network of the lung and its change with age, Thorax, 20, 469-476 (1965).

26) Johnson, J. R. and Andrews, F. A. : Lung scleroproteins in age and emphysema, Chest, 57, 239-244 (1970).

27) Low, F. N. : Extracellular components of the pulmonary alveolar wall, Arch. Intern. Med., 127, 847-852 (1971).

28) Bartlett, D. Jr., Faulkner II, C. S., and Cook, K. : Effect of chronic ozone exposure on lung elasticity in young rats, J. Appl. Physiol., 37, 92-96 (1974).

29) Pierce, J. A. and Hocott, J. B. : Studies of the collagen and elastin content of the human lung, J. Clin. Invest., 39, 8-14 (1960).

30) Rickert, W. S. and Forbes, W. F. : Changes in collagen with age II. Modification of collagen structure by exposure to the gaseous phase of tobacco smoke, Exp. Geront., 7, 99-109 (1972).

31) Stokinger, H. E. : Ozone toxicity. A review of research and industrial experience : 1954-1964, Arch. Environ. Health, 10, 719-731 (1965).

\section{オゾン暴露の肺及び皮膚コラーゲンへの影響}

\section{兵庫県衛生研究所}

\section{深 瀬 治・橋 本 清 澄}

オゾン繰り返し暴露のマウス及びラット肺及びラット皮膚コラーゲンへの影響を検討した。 $0.2-1.7 \mathrm{ppm}$ オゾン 5 日 暴露を行ったマウス肺では, オゾンの影響の指標として用いられる還元型グルタチオン量は濃度に比例して増加したが, コラーゲン量は変化しなかった。マウス肺コラーゲン量の有意の増加は $1.0 \mathrm{ppm}$ オゾン 40 日の暴露で起り, 増加したコ ラーゲンは, 暴露終了後還元型グルタチオンより緩やかに減少した。マウス及びラット肺コラーゲンの大部分は $0.5 \mathrm{M}$ 塩 化ナトリウム, $0.5 \mathrm{M}$ 酢酸, 及び $0.2 \mathrm{M}$ システアミン溶液に不溶で, その不溶解性は, ラットに $1.0 \mathrm{ppm}$ オゾン 10 週まで 
暴露しても変らなかった。また, $1.0 \mathrm{ppm}$ オゾン10週暴露したラット皮膚コラーゲンは, その溶解性及び量に変化が見ら れなかった。 